\title{
Description of a new species of Engraulicola George 1960 (Monogenea: Gastrocotylidae) parasitizing gills of Chloroscombrus chrysurus (Carangidae) from Veracruz, southern Gulf of Mexico
}

\author{
Descrição de uma nova espécie de Engraulicola George 1960 (Monogenea: \\ Gastrocotylidae) parasito de brânquias de Chloroscombrus chrysurus \\ (Carangidae) de Veracruz, Sul do Golfo do México \\ Jesús Montoya-Mendoza* @i); Guillermo Salgado-Maldonado²; Yuri Okolodkov³ \\ ${ }^{1}$ Laboratorio de Investigación en Acuacultura Aplicada, Tecnológico Nacional de México, Instituto Tecnológico de Boca del Río, Boca del \\ Río, Veracruz, México \\ ${ }^{2}$ Laboratorio de Helmintología, Instituto de Biología, Universidad Nacional Autónoma de México, Ciudad de México, México \\ ${ }^{3}$ Laboratorio de Botánica Marina y Planctología, Instituto de Ciencias Marinas y Pesquerías, Universidad Veracruzana, Boca del Río, \\ Veracruz, México
}

How to cite: Montoya-Mendoza J, Salgado-Maldonado G, Okolodkov Y. Description of a new species of Engraulicola George 1960 (Monogenea: Gastrocotylidae) parasitizing gills of Chloroscombrus chrysurus (Carangidae) from Veracruz, southern Gulf of Mexico. Braz J Vet Parasitol 2021; 30(1): e018420. https://doi.org/10.1590/S1984-296120201084

\begin{abstract}
Engraulicola lamothei n. sp. (Monogenea: Gastrocotylidae) is described from the gills of Chloroscombrus chrysurus (Teleostei: Carangidae) from Veracruz, southern Gulf of Mexico. This monogenean is 1110-1670 (1328) $\mu \mathrm{m}$ long and 260-550 (363) $\mu \mathrm{m}$ wide. The haptor is asymmetrical, the long side has several clamps (35-42), and the short side has a single clamp; the posterior end has a small lappet armed with two dissimilar pairs of hooks. Male and female genital pores open near the anterior body end; the male genital pore is ventral, armed with a corona of 12 spines; the female pore is dorsal and unarmed. The new species differs from Engraulicola forcipopenis George, 1960 and from Engraulicola micropharyngella Unnithan, 1967 by lacking a pair of pointed forceps-like spines at the end of the penis amid the corona spines, and from Engraulicola thrissocles Tripathi, 1959 by the number of clamps on both sides, the number the hook pairs on the terminal lappet and the testis number. This is the first record of the genus Engaulicola George, 1960 on the Atlantic West Coast.
\end{abstract}

Keywords: Engraulicola lamothei, marine fishes, Monogenea, morphology, parasites, Gulf of Mexico.

\begin{abstract}
Resumo
Engraulicola lamothei n. sp. (Monogenea: Gastrocotylidae) é descrito a partir das brânquias de Chloroscombrus chrysurus (Teleostei: Carangidae) de Veracruz, Sul do Golfo do México. Este monogêneo tem 1110-1670 (1328) um de comprimento e 260-550 (363) $\mu \mathrm{m}$ de largura. O "haptor" é assimétrico, o lado longo tem vários grampos (3542), e o lado curto tem um único grampo, e a extremidade posterior tem um pequeno "lappet" armado com dois pares de ganchos diferentes. Os poros genitais masculino e feminino são abertos perto da extremidade anterior do corpo; o poro genital masculino é ventral, armado com uma coroa de 12 espinhos; o poro feminino é dorsal e desarmado. A nova espécie difere de Engraulicola forcipopenis George, 1960 e de Engraulicola micropharyngella Unnithan, 1967, pela ausência de um par de fórceps pontiagudos como espinhos localizados na extremidade do pênis, em meio aos espinhos da coroa; e de Engraulicola thrissocles Tripathi, 1959, pelo número de pinças em ambos os lados, pelo número de pares de ganchos no "lappet" terminal, e pelo número de testículos. Este é o primeiro registro do gênero Engaulicola George, 1960 para a costa oeste do Atlântico.
\end{abstract}

Palavras-chave: Engraulicola lamothei, peixe marinho, Monogenea, morfologia, parasitos, Golfo do México.

Received August 06, 2020. Accepted November 16, 2020.

*Corresponding author: Jesús Montoya-Mendoza. E-mail: jesusmontoya@bdelrio.tecnm.mx

This is an Open Access article distributed under the terms of the Creative Commons Attribution License, which permits unrestricted use, distribution, and reproduction in any medium, provided the original work is properly cited. 


\section{Introduction}

During the helminthological analyses of Sciaenidae and Carangidae marine fishes off the coast of Veracruz, southern Gulf of Mexico, we collected ten monogeneans identified as Engraulicola cf. thrissocles (Tripathi, 1959), from Chloroscombrus chrysurus Linnaeus 1766 (Teleostei: Carangidae) (Montoya-Mendoza et al., 2008). Although the general morphology of our specimens closely resembled the species alluded to, other characteristics, further elaborated upon later, made us consider that they might be an as yet undescribed species in this genus. We performed another round of samplings between 2008 and 2012, aiming to collect additional specimens of this monogenean species; despite collecting only a few, we were able to confirm that it is indeed a new taxon, which we describe here. Besides our previous record, only one additional record of monogeneans in the Atlantic bumper (C. chrysurus) from the Gulf of Mexico is available. The parasite was Amphipolycotyle chloroscombrus Hargis, 1957, in spite of this, Yamaguti (1963) proposed the synonymy of Engraulicola and Amphipolycotyle, although A. chloroscombrus is still referred to as a valid species and has been recorded in the general geographic area of our specimen collection (Bravo-Hollis, 1984; Costa \& Chellappa, 2016). Currently, the genus Engraulicola George, 1960 (Monogenea: Gastrocotylidae: Gastrocotylinea) includes three valid species parasitizing Engraulidae fishes from the Indo-Pacific: E. forcipopenis George, 1960, E. micropharyngella Unnithan, 1967, and E. thrissocles (Tripathi, 1959) Lebedev, 1971 (George, 1960; Unnithan, 1967; Lebedev, 1972, 1986). In this study we describe the fourth species in this genus and provide prevalence and infection intensity data in C. chrysurus in the southern Gulf of Mexico.

\section{Materials and Methods}

We examined ten C. chrysurus specimens in October 2008 and a further ten in March 2012. All specimens were

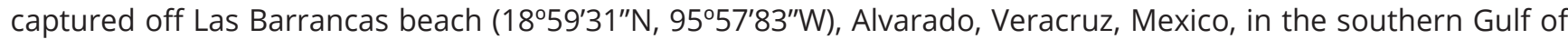
Mexico. Captured fish were transported live to the laboratory and examined during the subsequent 24 hours. We examined gills, opercula, nostrils, skin, and fins under a stereo microscope. Monogeneans were fixed in hot $4 \%$ formalin and stored in 70\% ethanol. The specimens were later stained with Mayer's paracarmine and Gomori's triple stain, gradually dehydrated in ethanol, cleared in clove oil, and mounted as whole specimens.

Some monogenean specimens were mounted in temporary preparations using ammonium picrate to examine sclerotized structures (Vidal-Martínez et al., 2001). Line drawings were made using an Olympus BX51 compound microscope and a camera lucida. Voucher specimens of Montoya-Mendoza et al. (2008), deposited in the Colección Nacional de Helmintos (CNHE; CNHE-6197, four specimens), were re-examined. Measures are given in micrometers with the range followed by the average in parentheses. We calculated the prevalence (percentage of infected hosts) and mean intensity (mean number of monogeneans per host), according to Bush et al. (1997). The holotype (CNHE no. 11439) and the paratype specimens ( $n=9$; CNHE no. 11440, 11441) were deposited in the Colección Nacional de Helmintos (CNHE), Instituto de Biología, Universidad Nacional Autónoma de México, Mexico City, Mexico.

\section{Results}

Class: Monogenea van Beneden, 1858

Order: Mazocraeidea Price, 1936

Family: Gastrocotylidae Price, 1943

Genus: Engraulicola George, 1960

Engraulicola lamothei $\mathrm{n}$. sp. (Figures 1-2).

Description (based on ten specimens). Lanceolate body narrowing toward the anterior end, length 1110-1670 (1328) $\mu \mathrm{m}$ from apex to posterior end; maximum width at ovary level 260-550 (363) $\mu \mathrm{m}$. Anterior end rounded (Figure 1). Smooth tegument. Lacking eyespots. Terminal mouth. With oral spheroid-shaped suckers anterior and lateral to the pharynx; left sucker 22-25 (24) $\mu \mathrm{m}$ long, 25-30 $\mu \mathrm{m}$ (27) wide; right sucker 22-27 (25) $\mu \mathrm{m}$ long, 25-27 (26) $\mu \mathrm{m}$ wide.

Ovoid pharynx 25-37 (31) $\mu \mathrm{m} \times$ 30-37 (35) $\mu \mathrm{m}$. Simple esophagus, long and narrow, without ramifications; intestinal crura anterior to the male genital pore. Caeca simple, terminating near the posterior end of the body, not confluent. Asymmetric haptor, with a long row of 32-42 clamps on one side and a single clamp on the opposite side; the longest part measures 740-1050 (897) $\mu \mathrm{m}$, extending as an adhered lateral expansion over $\sim 50 \%$ of the body length. Amphipathic haptor; when the parasite was found in the host's right gill chamber, the long part of 


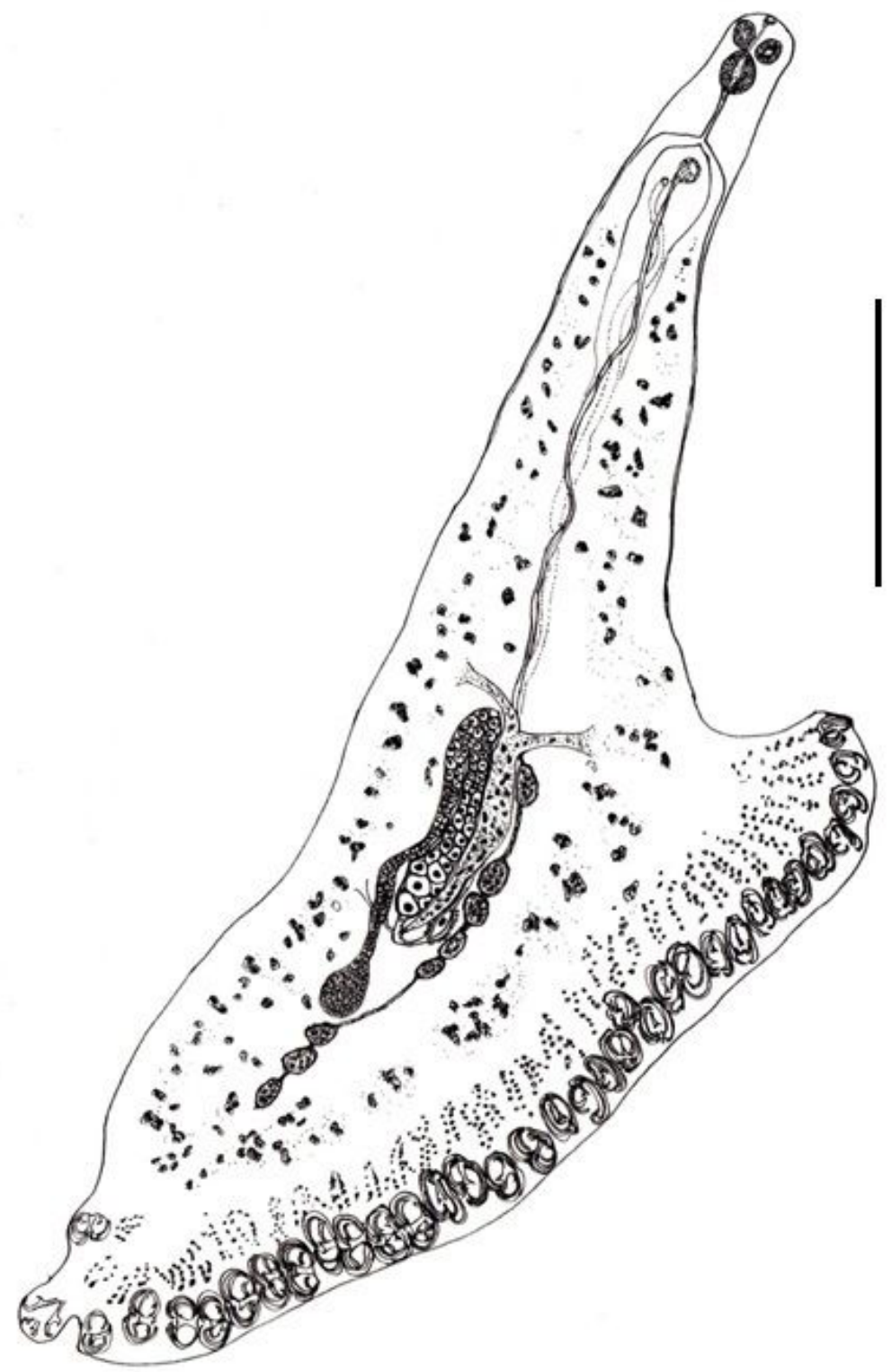

Figure 1. Engraulicola lamothei n. sp. from Chloroscombrus chrysurus. Entire worm, dorsal view; holotype (CNHE 11439).

the haptor was at the right side; the opposite occurred when the parasite was in the left gill chamber. All clamps are similar in shape with small variations in size (Figure 2a). The distal clamps measure 25-30 (27) $\mu \mathrm{m}$ long $\times 30-42$ (39) $\mu \mathrm{m}$ wide; medium clamps 27-35 (30) $\mu \mathrm{m} \times 37-50$ (44) $\mu \mathrm{m}$; proximal clamps 20-30 (25) $\mu \mathrm{m} \times 25-37$ (32) $\mu \mathrm{m}$; the single clamp of the short side of the haptor is 18-35 (25) long $\times 27-42$ (34) wide. The clamps present the typical structure of the Gastrocotyloidea family with a very short dorsal arm in the median spring and a V-shaped distal end; the ventral arm of the median spring is long and thin, with a bifurcated distal end extending to the superior level of the jaw sclerites; the base of each clamp shows a cuticularized ligament at both sides; the ventral and dorsal jaws are symmetrical; the dorsal arm of the ventral jaw extends to the terminal level of the dorsal arm of the median jaw; the oblique jaw sclerites are long and thin, with the distal end in contact with the median line (Figure 2a). The terminal lappet is trapezoid in shape, measuring 35-50 (43) $\mu \mathrm{m} \times 30-40$ (34) $\mu \mathrm{m}$ with two pairs of hooks; the proximal pair is larger, measuring 24-28 (27) $\mu \mathrm{m}$, and the distal pair is smaller, measuring 8-10 (9) $\mu \mathrm{m}$ (Figure 2b). Spheroid testes, 7-10 (8), arranged in a row, forming a string running more or less parallel to the anteroposterior axis of the body (Figures 1, 2d); the proximal testes measure 25-30 (26) $\mu \mathrm{m}$ long x 25-50 (33) $\mu \mathrm{m}$ wide; the distal testes measure 25-35 (28) $\mu \mathrm{m} \times 27-40$ (31) $\mu \mathrm{m}$. Straight Vas deferens, opening at the base of the male copulating organ. Median genital atrium, located ventrally, posterior to the caecal bifurcation, opening at 
150-200 (168) $\mu \mathrm{m}$ from the anterior end of the body. The penis is a bulbous muscle crowned with 12 spines with converging uncinated tips; spines measure 11-18 (13) $\mu \mathrm{m}$ long x 13-21 (16) $\mu \mathrm{m}$ wide (Figure 2c). The ovary is an elongated, inverted U-shaped, located almost symmetrically to the testes; the ovary has a short oviduct that in

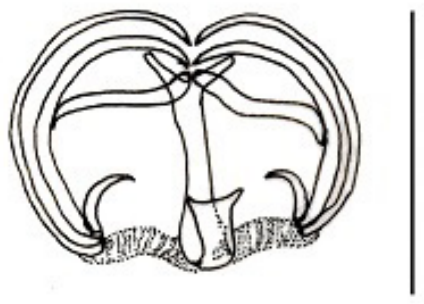

a
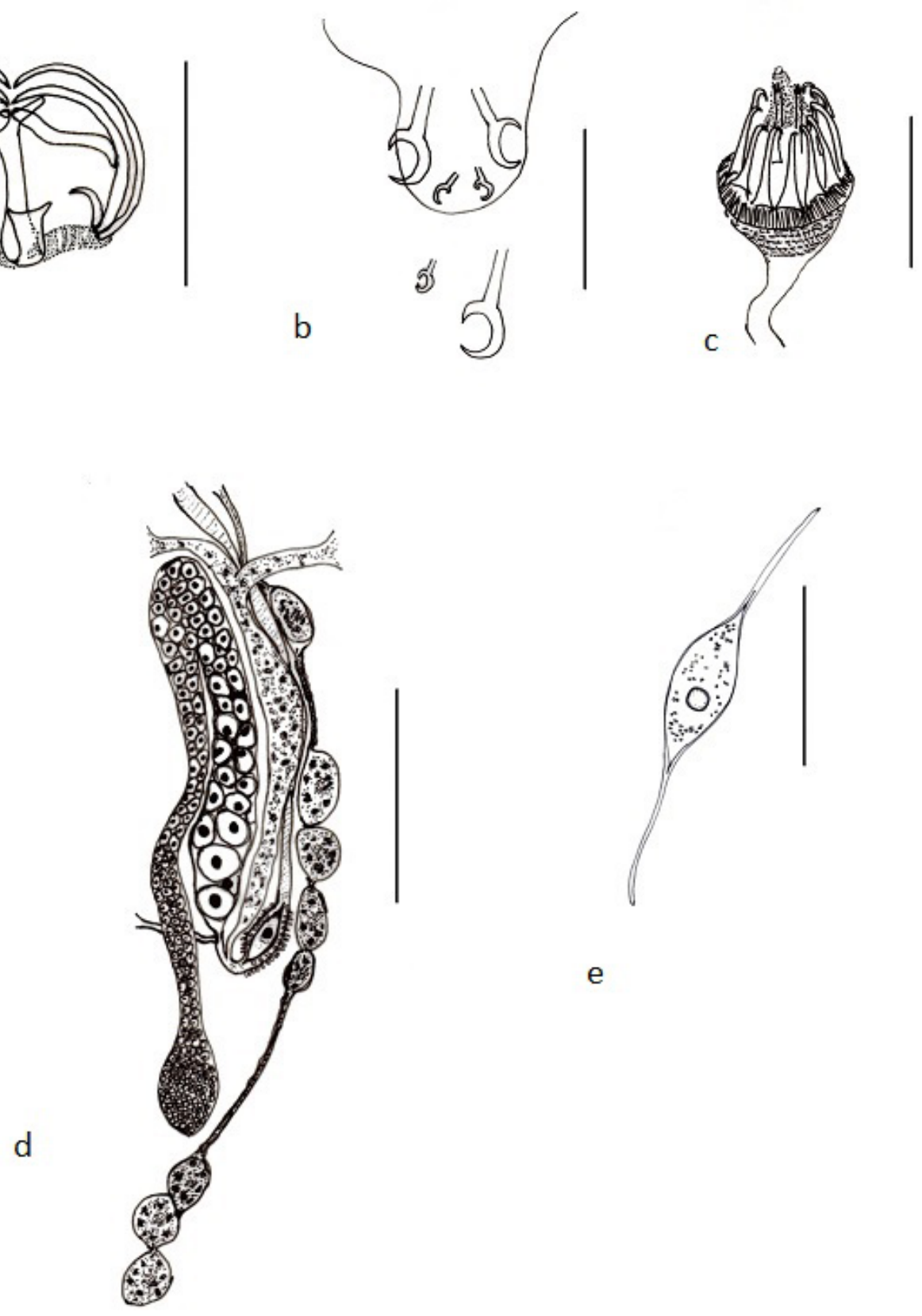

e

Figures 2. Engraulicola lamothei n. sp. from Chloroscombrus chrysurus. Figure 2a. Clamps. Figure 2b. Hook. Figure 2c. Male copulatory organ. Figure 2d. Ovarian region. Figure 2e. Eggs. Scale bars: Figure 1 - $200 \mu$ m. Figure 2a, 2b, 2e - 50 $\mu$ m; Figure 2c $-20 \mu \mathrm{m}$; Figure $2 \mathrm{~d}-100 \mu \mathrm{m}$. 
turn opens into the ootype. The uterus originates from the ootype, extending upwards and opening in proximity to the male genital pore (Figure 1). The vitelline glands extend through the lateral fields from the caecal branching zone almost to the terminal end of the body, converging toward the final region of the intestinal caeca. The vitelline receptacle is conspicuous, V-shaped, located between the ovary and the string of testes. Unarticulated vaginal pore, opening in the dorsal surface posterior to the genital atrium. The genito-intestinal canal connects the ootype with an intestinal caecum (Figure 2d). The eggs are elliptical in shape, measuring 157-166 (161) $\mu \mathrm{m} \times 45-50$ (47) $\mu \mathrm{m}$ with two short polar filaments (Figure 2e).

Locality: Off Las Barrancas beach (185'31"N, 9557'83"W) Alvarado, Veracruz, Mexico, southern Gulf of Mexico. Site of infection: gills.

Dates of collection: October 2008 and March 2012.

Prevalence, 40\% (4/10 hosts), 7 monogeneans collected, mean intensity 1.75, range 1-3 (October 2008); 20\% (2/10 hosts), 3 monogeneans collected, mean intensity 1.5, range 1-2 (March 2012).

Etymology: this species is named in honor of the late Mexican helminthologist Dr. Marcos Rafael Lamothe $y$ Argumedo (1932-2013), Instituto de Biología, Universidad Nacional Autónoma de México, México.

\section{Remarks}

The analyzed material shows the identifying characteristics of the genus Engraulicola according to George (1960) and Lebedev $(1972,1986)$, including: the presence of an asymmetrical haptor with one well-developed side with numerous clamps and an opposite sub-developed side with a single clamp; a terminal caudal lappet in the shape of a small digitiform projection; two pairs of differently sized hooks; clamps are long rather than wide; testes as rounded follicles, arranged in a row forming a string; vagina dorsal and unarticulated; eggs possessing polar filaments.

The new species, Engraulicola lamothei, is more similar to E. thrissocles, given a number of characteristics, including: general anatomical structure, the lack of forceps-like spines in the spine crown surrounding the penis, the number of spines constituting this crown, the shape of the clamps in the haptor and the possession of an inverted U-shaped ovary (see Tripathi, 1959). However, it can be distinguished from the latter species by the total number of clamps in the haptor, 33-43/1 in the new species compared with 46-59/1-2 in E. thrissocles; the caudal lappet is smaller $(30-40 \mu \mathrm{m} \times 35-50 \mu \mathrm{m})$ and has two pairs of hooks in the new species, whereas in $E$. thrissocles it is larger $(75 \mu \mathrm{m} \times 77 \mu \mathrm{m})$, with three pairs of hooks. Moreover, E. lamothei has fewer testes (7 a 10) than E. thrissocles (20-40); the proximal clamps are smaller in E. lamothei (25-30 $\mu \mathrm{m} \times 30-42 \mu \mathrm{m})$ compared to E. thrissocles $(43-52 \mu \mathrm{m} \times 39-60 \mu \mathrm{m})$, and E. lamothei $\mathrm{n}$. sp. is smaller overall $(1110-1670 \mu \mathrm{m})$ than E. thrissocles (2600-3500 $\mu \mathrm{m})$ (see Table 1).

The other two species of Engraulicola, E. forcipopenis and E. micropharyngella, show a characteristic pair of forceps-like spines emerging from the central part of the spine crown surrounding the penis, making them different from the new species (George, 1960; Unnithan, 1967). Furthermore, E. lamothei n. sp. possesses fewer testes (8-10) than E. forcipopenis (14-18), and its eggs are smaller (157-166 $\mu \mathrm{m} \times 45-50 \mu \mathrm{m})$ than those of E. forcipopenis $(168-210 \mu \mathrm{m} \times 50-84 \mu \mathrm{m})$. The pharynx of E. lamothei $\mathrm{n}$. sp. is larger (25-37 $\mu \mathrm{m} \times 30-37 \mu \mathrm{m})$ than that of E. micropharyngella (14); the number of spines in the crown of the penis (12), as well as the number of clamps in the haptor (33-43), is also greater in E. lamothei $\mathrm{n}$. sp. than in E. micropharyngella (8-10 spines; 27 clamps), whereas the number of testes $(7-10)$ is fewer in the new species than in E. micropharyngella (27 testes). Finally, the size of the eggs varies widely, 157-166 $\mu \mathrm{m} \times 45-50 \mu \mathrm{m}$ in the new species compared with $24 \mu \mathrm{m} \times 40 \mu \mathrm{m}$ in E. micropharyngella (Table 1).

The proposed new species E. lamothei is similar to the currently valid species Amphipolycotyle chloroscombrus Hargis, 1957 because of the presence of a terminal lappet and larval hooks and because both species have a genital pore surrounded by a crown of 12 hooks. However, these species can be differentiated by the number of clamps (33-43/1 in E. lamothei n. sp. vs 15-18 on the long side, plus 9-16 on the short side in A. chloroscombrus); the number and length of the larval hooks on the terminal lappet (2 pairs in E. lamothei $\mathrm{n}$. sp., the proximal $24-28 \mu \mathrm{m}$ and the posterior pair 8-10 $\mu \mathrm{m}$, compared to 3 pairs of larval hooks in A. chloroscombrus, the anterior pair 34-36 $\mu \mathrm{m}$ in length, the medium pair $24 \mu \mathrm{m}$ and the posterior ones $20 \mu \mathrm{m}$ ); and the number of testes (7 to $10 \mathrm{in}$ E. lamothei $\mathrm{n}$. sp. and 2 in A. chloroscombrus). 
Table 1. Comparative morphological characteristics of the species of the genus Engraulicola; measurements are presented as length $(\mathrm{l}) \times$ width $(\mathrm{W})$ in micrometers.

\begin{tabular}{|c|c|c|c|c|}
\hline & E. forcipopenis & E. micropharyngella & E. thrissocles & E. Iamothei n. sp. \\
\hline Hosts & Anchoviella bataviensis & $\begin{array}{l}\text { Anchoviella } \\
\text { commersonii }\end{array}$ & Thryssa mystax & $\begin{array}{l}\text { Chloroscombrus } \\
\text { chrysurus }\end{array}$ \\
\hline Location & $\begin{array}{l}\text { India, Arabian Sea, NW } \\
\text { Indian Ocean }\end{array}$ & $\begin{array}{l}\text { India, Arabian Sea, NW } \\
\text { Indian Ocean }\end{array}$ & $\begin{array}{l}\text { India, NW Indian Ocean, } \\
\text { Vietnam, NW Pacific }\end{array}$ & $\begin{array}{l}\text { Mexico, Gulf of Mexico, } \\
\text { NW Atlantic Ocean }\end{array}$ \\
\hline Length & $1900-2200$ & $1300-1900$ & $2600-3500$ & $1110-1670$ \\
\hline Width & $520-820$ & $420-640$ & $370-380$ & $260-550$ \\
\hline Number of clamps & $25-44 / 1$ & 27/jan & $46-59 / 1-2$ & $35-42 / 1$ \\
\hline Proximal (I x w) & $21-33 \times 33-50$ & $16 \times 20$ & $43-52 \times 39-60$ & $20-30 \times 25-37$ \\
\hline Medial & $21-42 \times 50-84$ & $28 \times 40$ & & $27 \times 35 \times 37-50$ \\
\hline Opposite & $25-33 \times 30-42$ & $25-33 \times 30-42$ & $26-36 \times 34-45$ & $18-35 \times 27-42$ \\
\hline Oral suckers (I x w) & $25-37 \times 37-50$ & $16-20$ & 19 & $22-27 \times 25-30$ \\
\hline Pharynx (I x w) & $38-42 \times 50-59$ & 14 & $26 \times 45$ & $25-37 \times 30-37$ \\
\hline Number corona spines & 12 & 08/oct & 12 & 12 \\
\hline Diameter corona spines & $16-18$ & - & - & $13-21$ \\
\hline Terminal lappet & -- & $36 \times 21$ & $75 \times 77$ & $43 \times 34$ \\
\hline Pairs hooks & 2 & 2 & 3 & 2 \\
\hline Proximal & $25.4-29.2$ & 24 & 35 & $24-28$ \\
\hline Medial & 12.6 & 8 & 14 & 08/oct \\
\hline Distal & - & - & 02/apr & - \\
\hline Number of testes & $14-18$ & 27 & $20-40$ & 07/oct \\
\hline Eggs & $168-210 \times 50-84$ & $40 \times 24$ & - & $157-166 \times 45-50$ \\
\hline References & George (1960) & Unnithan (1967) & Lebedev (1972) & Present study \\
\hline
\end{tabular}

\section{Discussion}

The study of additional specimens allowed us to confirm that the specimens, previously reported by us as E. cf. trissocles (CNHE 6197) (Montoya-Mendoza et al., 2008), are indeed a new species currently identified as Engraulicola lamothei $\mathrm{n}$. sp. This new species is morphologically well differentiated from the three previously known species of Engraulicola and also from the currently valid species A. chloroscombrus; furthermore, we include a key to species in Engraulicola to differentiate between these species.

The three previously known species of the genus Engraulicola are parasites of the fish family Engraulidae in the Indo-Pacific (Table 1). The data hereby demonstrate that this monogenean group can be found parasitizing other fish families, such as Carangidae in this study, even in locations far from the Indo-Pacific such as the Gulf of Mexico. This discontinuity of geographical distribution is remarkable; however, engraulid fish are widely distributed, and the data presented here suggest that additional Engraulicola species might be encountered in other fish families. Thus, the real geographical distribution of this group of monogeneans is far from completely known, as is also true for most parasites. Therefore, additional sampling is needed to understand the question posed by our current report.

The present finding of a new species of Engraulicola parasitizing marine carangid fish in the southern Gulf of Mexico highlights the discussion regarding the supposed synonymy of Engraulicola and Amphipolycotyle (Yamaguti, 1963). From our point of view, and as far as the present comparison between structural characteristics of our species versus those of $A$. chloroscombrus, there are sufficient differences between both genera, including the number of clamps and larval hooks on lappet and the number of testes. These differences allow us to consider them different genera. 
Key to species of Engraulicola

1 Pair of forceps-like spines emerging from the central part of male copulatory organ .2

- No forceps-like spines from the central part of male copulatory organ 3

2 With 8 -10 spines in the genital corona; testes, 27; clamps, 27-32/1. E. micropharyngella

- With 12 spines in the genital corona; testes, 14-18; clamps, 33-44/1

3 Three pairs of hooks on the caudal lappet; testes, 20-40 E. forcipopenis

- Two pairs of hooks on the caudal lappet; testes, 7-10 E. thrissocles

\section{Acknowledgements}

Igor S. Smirnov from the Zoological Institute of the Russian Academy of Sciences, St. Petersburg, Russia, is thanked for his help in obtaining some valuable literature. This study was a part of the PhD thesis conducted by the first author, sponsored by scholarship granted by the Mexican Council for Science and Technology (CONACyT), No. 188620. Marcia M. Gowing (Seattle, Washington, USA) kindly corrected the English.

\section{References}

Bravo-Hollis M. Monogenea (van Beneden, 1858) Carus, 1863 de peces del litoral mexicano del Golfo de México y del Mar Caribe X. Nuevas localidades de colecta de seis especies conocidas. An Inst Biol Univ Nac Auton Mex Ser Zool 1984; 55(1): 61-71.

Bush AO, Lafferty KD, Lotz JM, Shostak AW. Parasitology meets ecology on its own terms: margolis et al. revisited. J Parasitol 1997; 83(4): 575-583. http://dx.doi.org/10.2307/3284227. PMid:9267395.

Costa E, Chellappa S. First record of Amphipolycotyle chloroscombrus Hargis, 1957 (Monogenea, Polyopisthocotylea, Gastrocotylidae) in the South Atlantic Ocean. Braz J Oceanogr 2016; 64(1): 101-104. http://dx.doi.org/10.1590/S1679-87592016098406401.

George KC. On a new gastrocotylid trematode, Engraulicola forcipopenis gen. et sp. nov. on white-bait, from Southern India. J Mar Biol Assoc India 1960; 2(2): 208-215.

Lebedev BI. Monogenea: suborder Gastrocotylinea. Leningrad: Nauka; 1986. In Russian.

Lebedev BI. The taxonomy of monogeneans of suborder Gastrocotylinea. Trudy biol.-pochvenn. Inst Vladivostok 1972; 11: 121 -145.

Montoya-Mendoza J, Salgado-Maldonado G, Mendoza-Palmero CA. Monogenean parasites of Carangidae and Sciaenidae marine fish on the Alvarado coast, Veracruz, Mexico, south Gulf of Mexico. Zootaxa 2008; 1843(1): 47-56. http://dx.doi.org/10.11646/ zootaxa.1843.1.4.

Tripathi YR. Monogenetic trematodes from fishes of India. Indian J Helminthol 1959; 9(1-2): 1-149.

Unnithan RV. On some Gastrocotyline (Monogenoidean) parasites of Indian clupeoid fishes, including three new genera. Pac Sci 1967; 21(2): 210-229.

Vidal-Martínez VM, Aguirre-Macedo ML, Scholz T, González-Solís D, Mendoza-Franco EF. Atlas of the helminth parasites of cichlid fish of Mexico. Prague, Czech Republic: Academy of Sciences of the Czech Republic; 2001.

Yamaguti S. Systema helminthum. New York: Wiley Interscience; 1963. (Monogenea and Aspidocotylea; vol. IV). 